To cite this article: Adebayo Muritala Adegbore, \& Akinyosoye Tolulope Omowumi (2021) Factors Influencing Electronic Medical Record Systems Success in Selected Tertiary Healthcare Facilities in South-West, Nigeria. Information Impact: Journal of Information and Knowledge Management, 11:4, 14-32, DOI: https://dx.doi.org/10.4314/iijikm.v12i1.2

To link to this article: https://dx.doi.org/10.4314/iijikm.v12i1.2

\title{
Factors Influencing Electronic Medical Record Systems Success in Selected Tertiary Healthcare Facilities in South-West, Nigeria
}

\author{
${ }^{1}$ Adebayo Muritala Adegbore \\ ${ }^{1}$ Akinyosoye Tolulope Omowumi \\ ${ }^{1}$ Department of Library, Archival and Information Studies, University of Ibadan, Nigeria
}

\begin{abstract}
Survey research design of the correlational type was employed for this study using stratified random sampling to select two hundred and forty-five (245) respondents. The research instrument which was a structured questionnaire was tagged Adoption Factors and Usage Evaluation of Electronic medical record systems System Success. A total of 222 copies research questionnaire were filled and returned. A statistical package for social science application was used in analysing the results of the research using Pearson Product Moment Correlation Coefficient for hypotheses one and two, and multiple regression analysis for the hypotheses three and four. The result from the study revealed that there was a positive significant correlation between adoption factors and EMRS systems' success $(r=0.440)$ and there was a strong positive correlation between usage evaluation and system success of EMRS in the two healthcare facilities $(r=0.618)$. More so, findings showed that adoption factors jointly and significantly affect EMRS system success with coefficient of 0.648 , and a multiple R square of 0.420 . And there was also a relative contribution of adoption factors $(\beta=0.215)$ and usage evaluation (0.526) on EMRS success. The study concludes that electronic medical record systems have become a standard for every healthcare facility for improvement in the efficiency and profitability of the organisations. The study therefore recommends that, all healthcare facilities in Nigeria should adopt the electronic medical record systems, and all healthcare providers should be given thorough training on the use of EMRS.
\end{abstract}

Keywords Electronic Medical Records, System Success, Medical Records, Information Systems

CONTACT:Adebayo Muritala. Adegbore and Akinyosoye Tolulope Omowumi adebayoadegbore@yahoo.com Department of Library, Archival and Information Studies, University of Ibadan, Nigeria

2021 The Authors Published with License by Information Impact

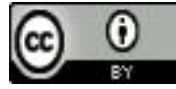




\section{Introduction}

The invention of new technologies has impacted every sector of human activities globally. Health, education, taxation sectors and etcetera, have been taken over by new technologies which has brought about many benefits to the running of the activities in these sectors. There is now much dependence on technology in our daily activities; while there is also high increase in the demand for technology. For example, technology is being relied upon for communicating, travelling issues, business and even pleasure such as living a comfortable life (Karehka, 2012). The impact of new computer technologies cannot be overemphasized in the health sector as it has paved way for a lot of improvement and efficiency in the activities of healthcare delivery organisations. Nigerian hospitals now operate in new dimensions, which made it possible for easy access to quality health care services in the various level of healthcare facilities, i.e, the primary, secondary and the tertiary health care facilities.

In Nigeria today, one could say that a tertiary healthcare facility operates all the levels of healthcare ( i.e, primary, secondary and tertiary levels of health care), because larger percentage of the healthcare resources are given to the tertiary healthcare facilities by the government, leaving the primary health care facilities (which are supposed to be the point of first contact with health care) with little or no resources to cater for the health challenges of the people in the community. As the tertiary healthcare facilities serve as the mother for all kinds of healthcare services in Nigeria, various types of medical records are kept in these facilities. The basic medical records kept by these hospitals are diagnostic summary index, master name index, admission and discharge records, general out-patients' records, obstetrics records, accident and emergency records, etcetera.

Records, according to the American Heritage Dictionary, cited by Onifade (2012) are "set of information or data based on a particular subject, collected, maintained and preserved" (p. 2). From this definition, records could be referred to as either a processed data or an unprocessed data that is first acquired, documented and maintained for present and future use. The latest improvement in technology has brought about the use of various types of computers and internet access information, and this had solved and is still solving various problems of people in today's world. As a result of this, most developed countries and very few developing countries had adopted the use of Electronic Health (eHealth), which includes the use of; electronic medical records, Health Information System, decision support system, telemedicine, etcetera, in healthcare services because of the numerous advantages it has over the manual medical records keeping system. Patient's medical information is now being captured using an electronic media and most especially the EMR system which has become more sophisticated day-in, day-out. Rouse (2011) define an Electronic Medical Records (EMR) as a digital form of the paper-based medical records for individuals. The Electronic medical record is a medical record within a single facility, such as a doctor's office or a clinic.

Electronic Medical Records (EMR) is application software that entails the pharmacy, computerised provider order entry, order entry, controlled medical vocabulary, clinical decision support, clinical data repository, and clinical documentation applications. This application software supports the patients' electronic medical records across inpatients and outpatient sections and it is used by medical professionals to capture, document, monitor and maintain healthcare delivery within a healthcare delivery organisation. There are various types of EMR and they are: Cranium Hospital Management System, Swiftpractice EMR, Care 360, Cerner EMR, Optum Physician EMR, Epic Care EMR, Kareo Clinical, Praxis EMR, Open EMR, Nextech EMR, and etcetera. Adoption of EMR would facilitate easy capturing of patients' information, accuracy in consultation of physicians and effective and accurate statistical reports. The users of EMR include medical staff, administrative staff 
and patients. The main users are the medical staff who are medical records officers, nurses and physicians who uses EMR to access patient health information. (Parvin, Mahboobeh, \& Kavoos, 2014)

Despite the advantages provided by a computerised health system, few tertiary hospitals have included the EMR system into their hospital and clinical routines. It was also noted that there are barriers hindering the adoption of EMR system by the healthcare facilities (WHO, 2013). Such hindering factors may hinge on non-valuation of the existing adopted systems by the hospitals and as such, other hospitals that have not adopted may not have opportunity to compare and contrast let alone understanding the imminent benefits of implementing the system. Therefore, this research work would determine if the usage of EMR has met the stated needs of the two selected (Federal Medical Centre, Owo, Ondo State and Federal Teaching Hospital, Ido, Ekiti State) healthcare facilities. This would help the selected healthcare facilities to evaluate the usage of the Electronic medical records (EMR) and to determine what benefits it has brought to the organisation. It would also help other healthcare facilities who have not adopted the EMR to take note of the factors that can affect (positively or negatively) the adoption of EMR and how best this factors could be utilized to bring about profitability and efficiency in their organisations.

\section{Research objectives}

The broad objective of this study was to evaluate success of EMR adopted by tertiary hospitals in Nigeria. The specific objectives were to:

1. determine the influence of technological factors on the adoption of EMR by the two healthcare facilities (Federal Medical Centre, Owo, Ondo State and Federal Teaching Hospital, Ido, Ekiti State);

2. find out the significance of organisational factors on the adoption of EMR by the two healthcare facilities;

3. ascertain the significance of healthcare providers' factors on adoption of EMR by the two healthcare facilities;

4. measure the influence of funding pattern on the adoption of EMR by the two healthcare facilities;

5. determine the quality of EMR in the two healthcare facilities; and

6. ascertain the system success of the adopted EMR in the two healthcare facilities.

\section{Research questions}

The following research questions were raised during the course of this study:

1. What is the influence of technological factors on the adoption of EMR by the two healthcare facilities?

2. What is the significance of organisational factors on the adoption of EMR by the two healthcare facilities?

3. What is the significance of healthcare providers' factors on adoption of EMR by the two healthcare facilities?

4. What is the influence of funding pattern on the adoption of EMR by the two healthcare facilities?

5. What is the quality of EMR in the two healthcare facilities?

6. What is the system success of the adopted EMR in the two healthcare facilities? 


\section{Review of related literature}

In the study carried out by Hussein, Karim and Selamat, (2007), findings indicated that technological factors are significantly correlated with the four IS success dimensions stated by DeLeone and MacLean. The study concludes that the technological factors investigated were very important in ensuring the successful utilization and implementation of information systems in the electronic government agencies which could also be related to hospital information system. Alam, Masum, Beh and Hong (2016) also identified the technological dimension as the most important dimension for hospital information system (HIS) adoption in the hospitals. Byrd and Turner, 2010 found that organizations with a team of highly technical staff tend to have better IT infrastructure flexibility, and at the same time are able to increase the organization's competitive advantage in key business management areas. In another study, Bradley, Byrd, Pridmore, hrasher, Pratt, and Mbarika, (2012) found that IT department technical quality which includes staff competency, had an influence on IT impact on the supply chain that leads to the firm's performance. From the above, we believe that, the IS competency factor is one of the important technological factor that would influence IS success.

Krist (2015) identified some of the barriers to EMR system adoption among many healthcare providers. Healthcare providers may be reluctant to accept EMR technology for a number of reasons, including the perception that the use of an EMR system requires extensive training, and interferes with the quality of physician-patient interaction. Moreso, other factors include, spending more time to get acquainted with the system, etcetera. While the validity of these issues have been addressed in a number of previous studies, it is important to note that healthcare providers' acceptance of EMR technology is dependent on the healthcare providers' perceptions. Incessant abandonment after adoption of information systems have been identified in libraries and other information centres (Adegbore, 2018) and this is also true of hospitals.

Moreso, Al-Mamary, Shamsuddin, and Hamid (2015) found that it is reasonable that, when top management consecrate a high level of necessary resources to support IT; they resort to embrace a better utilize of IS within an organization; meanwhile, if senior managers support using an IS, they may establish a reward system to prompt the employee to use the IS. According to Young and Jordan (2008), as senior managers can influence the implementation and use of new technologies, involves managers devoting time to the technology in proportion to its costs and potential, as well as reviewing plans, monitoring results and facilitating the management problems involved with integrating the technology with the management process of the business. Dong et al. (2009) also maintain that top management support encourages technology usage and better user performance, influences positive user perceptions and improves the overall technology adoption uptake.

Lian, Yen, and Wang (2014) reported that senior executives such as Chief Information Officer (CIO), Chief Executive Officer (CEO), and other senior executives play a vital role in usage of ISs at organisational level. They further stated that senior executives' direct involvement in IS activities is not only an indication of the significance of IS, but also guarantee their support and cooperation for the overall success of the IS initiatives in the organisation. A contemporary study by Al-Qirim, (2008) revealed that electronic commerce adoption in New Zealand is positively affected by CEO innovativeness. Consistent with prior studies, a study on small and medium-sized enterprises (SMEs) claimed that owner's IT ability and innovativeness were significant factors to adopting electronic commerce applications in Indonesia. Fei \& Shera (2011) cited in Macharia (2013) in their research on understanding hospital information systems (HIS) adoption in china also argued that hospitals are responsible for making the HIS investments and the decisions of whether and how to adopt HIS solely rest on the hospital executives (who are referred to as the top 
management staff in this research context). They also explained that strong commitment from the executives ensure the deployment of adequate financial and human resources as well as the careful implementation of the HIS adoption plan. It is also able to influence the other adoption factors such as user acceptance to improve the chance of successful system adoption. As a result, HIS adoption projects are commonly nicknamed the executive's project in China and as the IT manager revealed: If one hospital failed to adopt HIS, there must be some problem with their hospital top management staff.

The World Health Organization recommends supporting and strengthening a health system and there are six Building blocks of Health System Strengthening which includes; Human resources for health; health finance; health governance; health information; medical products, vaccines, and technologies and service delivery. Each component has interconnecting roles and functions. Strengthening a health system takes a long time. Efforts must be tailored to a specific country. Donors must be coordinated. Everyone involved must be committed to a long-term process. The way a country finances its health care system is an extremely important factor for reaching universal health coverage (UHC), because it determines the affordability of the available health services by those that need them.

Health financing systems should be designed to; raise sufficient and sustainable financial resources for health, which are equitably, effectively and sustainably mobilized; pool and manage collected financial resources to guarantee equity in financing and utilization with adequate financial protection for all; and use financial resources to provide the right incentives for providers and users alike to facilitate efficiency and enhance financial sustainability. All these said objectives can be facilitated through three healthcare financing function which are; revenue raising, pooling, and purchasing

In Nigeria, the health sector is financed through different sources and mechanisms. The difference in the proportionate contribution from these stated sources determine the extent to which such health sector will go in achieving successful health care financing system (Uzochukwu, Ughasoro, Etiba, Okwuosa, Envuladu and Onwujekwe, 2016). Health care financing system is a process by which revenues are collected from primary and secondary sources, e.g., out-of-pocket payments (OOPs), indirect and direct taxes, donor funding, co-payment, voluntary prepayments, mandatory prepayment, which are gathered in fund pools so as to share risk across large population groups and using the revenues to purchase goods and services from public and private providers for identified needs of the population, e.g., fee for service, capitation, budgeting, purchase and maintenance of EMR and salaries. Therefore, in a most basic form, health care financing represents a flow of funds from patients to health care providers in exchange for services. The way a health system is financed shows if the people get the needed health care and whether they suffer financially at the point of receiving care.

Health financing greatly influences the development, implementation, and sustainability of a national-level HER/EMR. Even when there is substantial donor support for the information system, there are direct and indirect costs for hardware, software, routine maintenance, and any necessary security enhancements. There were also costs to network the health facilities internally and externally. Human resources costs also apply to the development and maintenance of the EHR, including training costs (which are continuous owing to staff turnover and the need for refresher trainings); change management; and logistics, such as transport and fuel costs. Health financing is fundamental to the ability of health systems to maintain and improve human welfare. At the extreme, without the necessary funds no health workers would be employed, no medicines would be available 
and no health promotion or prevention would take place. However, financing is much more than simply generating funds. To understand the nature of the indicators that can be used to monitor and evaluate health system financing requires explicit assessment of what it is expected to achieve. In most developed countries, health care is paid for largely by the government or an organization associated with it, using taxes collected from citizens. The United Kingdom, for example, has a "single-payer" system in which the government pays directly for care.

Many studies have observed the importance of system quality on user satisfaction on different types of information systems. Gelderman, (2002) found system quality to be significantly related to user satisfaction of a management information system. Likewise, in a knowledge management system, system quality was also found to be strongly related to user satisfaction. In a study by Palmer (2002) on websites; system quality, measured as reliability and download time, was significantly related to user satisfaction. Perceived ease of use is the most common measurement of system quality due to the popularity of the theory of acceptance model (TAM) in research (Davies, 1989). Highly rated information system are expected to be reliable, user friendly, fast response, while also offering every functionality that places it above or at least at equal value with competing systems elsewhere. Ease of use could also be a relative term especially where one set are more technology inclined than the other. Nevertheless, the study confirms the universality of the system quality attribute in predicting IS performance, although the influence of system quality of the web portal on user satisfaction is poor (Ajoye, 2014). Another study of university support services found a relationship between service quality and user satisfaction and identified software upgrades, staff response time, and documentation of training materials as the service quality factors having the most influence on user satisfaction (Shaw et. al., 2002).

EMR offers quick service and minimizes medical error by reducing the use of papers in our healthcare facilities. Often times, the problem of inadequate treatment, over use of medications and incorrect diseases and operations code number are rooted from inability of the healthcare providers to read the doctor's handwriting. It may sometimes be as a result of paper deterioration. Furthermore, when a patient visits the hospital regularly, his medical records increases in volume as a result of the paper records used for them. This subsequently, affects the quality of health service offered, and much time is also spent (Ndukwe \& Ezeoha, 2018). Professional, timely and accurate treatment decisions which could not be made from poor handwritten medical records could be made with EMR system. EMR system also offers a widespread platform that can be available to everyone in a healthcare facility at once. Hence, physicians and other healthcare providers can access a patient's medical data anytime and anywhere because the medical information are now digitized through EMR system. EMR reduces the waiting time of patients and inefficiency by simplifying the workflow in the healthcare facility and offering a quick and an easy access to a patient's record. EMR system provides patients with fast and easy access to a more organised and efficient patientcentered health system. (MediFix, 2017).

There are many benefits to both the healthcare providers and consumer (patients) like fast access, storage, privacy, support, accessibility, affordability, technology, basic facilities, flexibility, efficiency, and manageability, etcetera (Ndukwe \& Ezeoha, 2018). More benefits include; reduction of preventable errors, improving communication among health care providers, controlling the cost of medical care, improved patient care, improved care coordination, practice efficiencies and cost savings, increased patient participation and improved diagnostic and patient outcomes. As already stated, EMRs and other decision support tools like computerised physician order entry (CPOE) help to reduce medical errors. For example, some clinical information systems (CIS) are able to check for 
drug allergies, drug doses and appropriateness of medication, thereby eliminating the need for physicians to write orders by hand in the patient's chart. Another important element of an EMR is legibility of clinical notes (Fraser, Biodich, Moodley. Choi, Mamlin, \& Szolovits, 2005). An EMR provides documentation in a computerised format that allows for data or records to be printed in text form rather than hand written. Also the computer makes spelling, validity and range checks which prompt users when data entry error is detected. An EMR also increases efficiency of healthcare providers' workflow. Thus, data entered into the hospital information system (HIS) can be used to refer a patient to a specialist.

Also, epidemiologists, researchers, physicians and other clinicians can extract information from HISs to protect and promote the health of the population through efficient surveillance, investigation, prevention and control of communicable diseases of public health importance. Further, an EMR allows care providers an opportunity to be abreast of patient health status. For instance, by creating shortcuts to documents warning about abnormal laboratory examination results, prescriptions and drug administration, physicians are able to quickly provide feedback to patients without any difficulties. Other identified benefits of EMR include data accessibility by multiple users and continuous data processing as well as automatic data back up and stored at different locations outside the hospital or clinics so that in case of disaster access to the record will not be denied (Fraser, Biodich, Moodley. Choi, Mamlin, \& Szolovits, 2005).

\section{Methodology}

This study adopted survey research design. The population of the study consisted of 200 medical doctors (both consultants and medical officers), 582 Nurses, 85 Medical records practitioners and 49 pharmacists from the Federal Medical center, Owo and Federal Teaching Hospital, Ido, Ekiti-state. This population included consultants, senior registrars, registrars, higher nursing officers, lower nursing officers, health records officers, health records technicians, and pharmacists. This means the total population of Health care professionals in the two tertiary hospitals was 916. The research instrument captured a total of 245 Healthcare professionals using a sampling frame; 53 Medical Doctors, 23 Medical Records Officers, 156 Nurses and 13 Pharmacists in the two tertiary healthcare facilities.

Table 1: Population of the study

\begin{tabular}{|l|l|l|l|}
\hline & $\begin{array}{l}\text { Federal medical centre, } \\
\text { Owo, Ondo state }\end{array}$ & $\begin{array}{l}\text { Federal Teaching Hospital, } \\
\text { Ido, Ekiti state }\end{array}$ & $\begin{array}{l}\text { Grand } \\
\text { Total }\end{array}$ \\
\hline Name of EMR in use & Cranium & Mediaville & \\
\hline Population of MRO & 55 & 30 & 85 \\
\hline $\begin{array}{l}\text { Population of } \\
\text { Nurses }\end{array}$ & 362 & 220 & 582 \\
\hline $\begin{array}{l}\text { Population of } \\
\text { medical doctors }\end{array}$ & 104 & 96 & 200 \\
\hline $\begin{array}{l}\text { Population of } \\
\text { pharmacists }\end{array}$ & 24 & 25 & 49 \\
\hline Total & 545 & 371 & 916 \\
\hline
\end{tabular}

Stratified random sampling technique was used for selecting of the sample size for this study. In stratified random sampling the population is partitioned into subgroups called strata. From within the stratum, uniform random sampling is used to select a per-stratum sample. All per-stratum samples are combined to derive the stratified random sample. The sample size was calculated using the 
Cochran's sample size formula, while the sampling frame is represented in the table as shown below respectively;

Sample size calculation

$\mathrm{n}_{\mathrm{o}}=\frac{\left(\mathrm{Z}^{2} \mathrm{pq}\right)}{\mathrm{e}^{2}}$

Where:

e is the desired level of precision/ margin of error $=0.05$

$\mathrm{p}$ is the estimated proportion of the population which has the attribute in question $=0.5$ ( we assume

half of the total population)

$\mathrm{q}$ is $1-\mathrm{p}=1-0.5=0.5$

$\mathrm{Z}$ value is found in the $\mathrm{Z}$ table $=1.96$ (for $95 \%$ confidence level)

Therefore, $\mathrm{n}_{0}=\left((1.96)^{2} * 0.5 * 0.5\right)$

$$
0.05^{2} \quad=384.16
$$

To determine the population sample, we have:

$\mathrm{n}=\frac{\mathrm{n}_{\mathrm{o}}}{1+\left(\mathrm{n}_{\mathrm{o}}-1\right) / \mathrm{N}}$

Where $\mathrm{N}$ is the population size $=916$

$\mathrm{n}_{\mathrm{o}}$ is the Cochran's sample size recommendation $=384.16$

And $\mathrm{n}$ is the new adjusted sample size

So, $n=384.16$

$1+(384.16-1)$

$916 \quad=245$

Table 2: Sampling frame of the population

\begin{tabular}{|c|c|c|c|}
\hline $\mathbf{s} / \mathbf{n}$ & Healthcare practitioners & $\begin{array}{l}\text { Tota } \\
\text { I }\end{array}$ & $\begin{array}{l}\text { Sample size } \\
\text { (size of entire sample/population size) } \\
\text { size) }\end{array}$ \\
\hline 1 & Medical Doctors & 200 & $245 / 916 \times 200=53$ \\
\hline 2 & $\begin{array}{l}\text { Medical records } \\
\text { (MRO) }\end{array}$ & 85 & $245 / 916 \times 85=23$ \\
\hline 3 & Nurses & 582 & $245 / 916 \times 582=156$ \\
\hline 4 & Pharmacists & 49 & $245 / 916 \times 49=13$ \\
\hline & Total & 916 & 245 \\
\hline
\end{tabular}

Therefore, for this study, the sample population consisted of 245 healthcare professionals in Federal medical center, Owo and Federal Teaching Hospital, Ido, Ekiti-state which will consist of 53 medical doctors, 23 medical records officers, 156 nurses and 13 pharmacists.

This study adopted an adapted questionnaire synthesized from Adegbore (2018) and DeLone and McLean (2003) titled Adoption factors of integrated library management systems (ILMS) in selected Nigerian University Libraries and Model of Information system success respectively. This instrument was used to collect data on adoption factors and usage evaluation of Electronic Medical records system success in Federal medical center, Owo and Federal Teaching Hospital, Ido, Ekitistate. The research instrument consisted of ten (10) sections. The pre-test of the instrument was carried out in Federal Medical Center Ebute Metta, Lagos which is different from the geographical location of the study. Thirty copies of the questionnaire were distributed among the medical doctors, nurses, medical records officers and pharmacists in Federal Medical Center Ebute Metta, Lagos, this gave room for necessary amendments in the questionnaire, before it was finally administered to the 
respondents. Subsequently, Cronbachs' Alpha method was used to establish the reliability coefficient of the questionnaire. The measurement scale established the psychometric properties of the following using Cronbachs' Alpha reliability test: Section B: Adoption factors of electronic medical records ( $\alpha$ $=0.800)$, Section D-I: usage evaluation of EMR $(\alpha=0.93)$, Section J: systems' success of EMR ( $\alpha=$ 0.92). The collected data were analysed using statistical package for social sciences (SPSS) version 21. The copies of the questionnaire were compiled, sorted, recorded and documented. The research questions were analysed using frequency tables, means and standard deviation.

\section{Results and discussion}

Response to research question 1 on the influence of technological factors on adoption of EMR in the two healthcare facilities revealed that technological factors has a moderate influence on adoption of EMR in Federal Medical Center, Owo and Federal Teaching Hospital, Ido. The finding of this study corroborates findings from previous study by Alam, Masum, Beh \& Hong (2016) who identified the technological dimension as one of the most important dimension for hospital information system (HIS) adoption in the hospitals. Therefore, issues relating to technological factors are important in the adoption of electronic medical record, as equally reported by Adegbore (2018) in a library and information science adoption study.

Table 3: Influence of technological factors on the evaluation of EMR

\begin{tabular}{|l|l|l|l|l|l|l|l|}
\hline & Technological factors & S.A & A & S.D & D & $\bar{x}$ & $\begin{array}{l}\text { S } \\
\text { D }\end{array}$ \\
\hline 1 & Technology issues like, type of computers, network topology, & $80(3$ & 133( & $1(0$. & $8(3$. & 1. & 0. \\
& location of central hub etcetera were considered before the & 6.0 & 59.9 & $5 \%)$ & $6 \%)$ & 7 & 6 \\
& adoption of EMR & $\%)$ & $\%)$ & & & 5 \\
\hline 2 & The EMR system quality was considered when adopting EMR & $79(3$ & 131( & $2(0$. & $7(3$. & 1. & 0. \\
& system. & 5.6 & 59.0 & $9 \%)$ & $2 \%)$ & 7 & 6 \\
& & $\%)$ & $\%)$ & & & 1 & 4 \\
\hline 3 & The output quality such as readability, text and picture clarity, & $91(4$ & 108 & 10 & 13( & 1. & 0. \\
& etcetera of the EMR were adequately considered. & 1.0 & $(48.6$ & $(4.5$ & 5.9 & 7 & 7 \\
& & $\%)$ & $\%)$ & $\%)$ & $\%)$ & 5 & 9 \\
\hline 4 & Information quality of the EMR was taken into consideration & $94(4$ & 111( & $6(2$. & $3(1$. & 1. & 0. \\
& when adopting the EMR system. & 2.3 & 50.0 & $7 \%)$ & $4 \%)$ & 6 & 6 \\
& & $\%)$ & $\%)$ & & & 2 & 1 \\
\hline 5 & The aftersales service quality provided by the EMR system & $75(3$ & 113( & 12( & 15( & 1. & 0. \\
& service provider was considered when adopting the EMR. & 3.8 & 50.9 & 5.4 & 6.8 & 8 & 8 \\
& & $\%)$ & $\%)$ & $\%)$ & $\%)$ & 5 & 1 \\
\hline
\end{tabular}

Key: $S$. $A=$ strongly agree $A=$ Agree $S$. $D=$ strongly disagree $D=$ disagree

Response to research question 2 on the significance of organisational factors on the adoption of EMR by the two healthcare facilities revealed that organisational factor has a high significance on the adoption of EMR in Federal Medical Center, Owo and Federal Teaching Hospital, Ido. This finding is in line with Fei and Shera (2011) cited in Macharia (2013) who in their research on understanding hospital information systems (HIS) adoption in China argued that hospitals are responsible for making the HIS investments and the decisions of whether and how to adopt HIS solely rest on the hospital executives (who are referred to as the top management staff in this research context). They also explained that strong commitment from the executives ensure the deployment of adequate financial and human resources as well as the careful implementation of the HIS adoption plan. It is also able to influence the other adoption factors such as user acceptance to improve the chance of successful system adoption. As a result, HIS adoption projects are commonly nicknamed the executive's project in China and as the IT manager revealed: If one hospital failed to adopt HIS, there must be some problem with their hospital top management staff. 
Furthermore, Al-Mamary, Shamsuddin, and Hamid (2015) found that it is reasonable that, when top management consecrate a high level of necessary resources to support IT; they resort to embrace a better utilize of IS within an organization; meanwhile, if senior managers support using an IS, they may establish a reward system to prompt the employee to use the IS. According to Young and Jordan (2008), as senior managers can influence the implementation and use of new technologies, involves managers devoting time to the technology in proportion to its costs and potential, as well as reviewing plans, monitoring results and facilitating the management problems involved with integrating the technology with the management process of the business. Dong et al. (2009) also maintain that top management support encourages technology usage and better user performance, influences positive user perceptions and improves the overall technology adoption uptake.

Table 4: Significance of organisational factors on the evaluation of EMR by the healthcare facilities.

\begin{tabular}{|c|c|c|c|c|c|c|c|}
\hline $\begin{array}{l}\mathrm{S} \\
\mathrm{N}\end{array}$ & Organisational factors & S.A & $\mathbf{A}$ & S.D & D & $\bar{x}$ & $\begin{array}{l}\text { S } \\
\mathbf{D}\end{array}$ \\
\hline 1 & $\begin{array}{l}\text { Importance of the EMR system is well understood by the top } \\
\text { management staff. }\end{array}$ & $\begin{array}{l}101( \\
45.5 \\
\%)\end{array}$ & $\begin{array}{l}106( \\
47.7 \\
\%)\end{array}$ & $\begin{array}{l}3(1 \\
4 \%)\end{array}$ & $\begin{array}{l}12(5 \\
.4 \%)\end{array}$ & $\begin{array}{l}1 . \\
6 \\
6\end{array}$ & $\begin{array}{l}.7 \\
5\end{array}$ \\
\hline 2 & $\begin{array}{l}\text { Top management staff are fully in support of the EMR system } \\
\text { adoption. }\end{array}$ & $\begin{array}{l}111( \\
50.0 \\
\%)\end{array}$ & $\begin{array}{l}97(4 \\
3.7 \% \\
)\end{array}$ & $\begin{array}{l}5(2 . \\
3 \%)\end{array}$ & $\begin{array}{l}9(4 . \\
1 \%)\end{array}$ & $\begin{array}{l}1 . \\
6 \\
0\end{array}$ & $\begin{array}{l}.7 \\
2\end{array}$ \\
\hline 3 & $\begin{array}{l}\text { There is thorough supervision of the EMR system by the top } \\
\text { management staff. }\end{array}$ & $\begin{array}{l}84(3 \\
7.8 \% \\
)\end{array}$ & $\begin{array}{l}104( \\
46.8 \\
\%)\end{array}$ & $\begin{array}{l}13(5 \\
.9 \%)\end{array}$ & $\begin{array}{l}21(9 \\
.5 \%)\end{array}$ & $\begin{array}{l}1 . \\
8 \\
6\end{array}$ & $\begin{array}{l}.8 \\
9\end{array}$ \\
\hline 4 & $\begin{array}{l}\text { The top management staff keep the other staff (both middle staff } \\
\text { and lower staff) informed about new developments in our healthcare } \\
\text { facilities. }\end{array}$ & $\begin{array}{l}80(3 \\
6.0 \% \\
)\end{array}$ & $\begin{array}{l}126( \\
56.8 \\
\%)\end{array}$ & $\begin{array}{l}16(7 \\
.2 \%)\end{array}$ & - & $\begin{array}{l}1 . \\
7 \\
1\end{array}$ & $\begin{array}{l}.5 \\
9\end{array}$ \\
\hline 5 & $\begin{array}{l}\text { The top management staff are fully aware of the IT skills and abilities } \\
\text { of their subordinates. }\end{array}$ & $\begin{array}{l}65(2 \\
9.3 \% \\
)\end{array}$ & $\begin{array}{l}108( \\
48.6 \\
\%)\end{array}$ & $\begin{array}{l}18(8 \\
.1 \%)\end{array}$ & $\begin{array}{l}29(1 \\
3.1 \\
\%)\end{array}$ & $\begin{array}{l}2 . \\
0 \\
5\end{array}$ & $\begin{array}{l}.9 \\
5\end{array}$ \\
\hline 6 & $\begin{array}{l}\text { The users of the EMR were made to undergo various training on the } \\
\text { use of the EMR. }\end{array}$ & $\begin{array}{l}88(3 \\
9.6 \% \\
)\end{array}$ & $\begin{array}{l}112( \\
50.5 \\
\%)\end{array}$ & $\begin{array}{l}6(2 . \\
7 \%)\end{array}$ & $\begin{array}{l}10(4 \\
.5)\end{array}$ & $\begin{array}{l}1 . \\
7 \\
1\end{array}$ & $\begin{array}{l}.7 \\
3\end{array}$ \\
\hline 7 & Frequent training programmes were organised for the users of EMR. & $\begin{array}{l}78(3 \\
5.1 \% \\
)\end{array}$ & $\begin{array}{l}77(3 \\
4.7 \% \\
)\end{array}$ & $\begin{array}{l}22(9 \\
.9 \%)\end{array}$ & $\begin{array}{l}43(1 \\
9.4 \\
\%)\end{array}$ & $\begin{array}{l}2 . \\
1 \\
3\end{array}$ & $\begin{array}{l}1 . \\
1 \\
0\end{array}$ \\
\hline 8 & Users have received enough training needed to operate the EMR. & $\begin{array}{l}64(2 \\
8.8 \% \\
1\end{array}$ & $\begin{array}{l}84(3 \\
7.8 \% \\
1\end{array}$ & $\begin{array}{l}25(1 \\
1.3 \\
\%)\end{array}$ & $\begin{array}{l}41(1 \\
8.5 \\
\%)\end{array}$ & $\begin{array}{l}2 . \\
2 \\
0\end{array}$ & $\begin{array}{l}1 . \\
0 \\
7\end{array}$ \\
\hline 9 & $\begin{array}{l}\text { The top management staff gets feedback from their subordinates on } \\
\text { the use of EMR. }\end{array}$ & $\begin{array}{l}63(2 \\
8.4 \% \\
\text { ) }\end{array}$ & $\begin{array}{l}123( \\
55.4 \\
\%)\end{array}$ & $\begin{array}{l}11(5 \\
.0 \%)\end{array}$ & $\begin{array}{l}24(1 \\
0.8 \\
\%)\end{array}$ & $\begin{array}{l}1 . \\
9 \\
8\end{array}$ & $\begin{array}{l}.8 \\
7\end{array}$ \\
\hline $\begin{array}{l}1 \\
0\end{array}$ & Users complains about the strenuous activity of operating the EMR. & $\begin{array}{l}54(2 \\
4.3 \% \\
)\end{array}$ & $\begin{array}{l}82(3 \\
6.9 \% \\
)\end{array}$ & $\begin{array}{l}35(1 \\
5.8 \\
\%)\end{array}$ & $\begin{array}{l}51(2 \\
3.0 \\
\%)\end{array}$ & $\begin{array}{l}2 . \\
3 \\
7\end{array}$ & $\begin{array}{l}1 . \\
0 \\
8\end{array}$ \\
\hline
\end{tabular}




\begin{tabular}{|l|l|l|l|l|l|l|l|}
\hline 1 & Users easily adapted with the new EMR system. & & & & & & \\
\hline 1 & & $46(2$ & $97(4$ & $24(1$ & $52(2$ & 2. & 1. \\
& & $0.7 \%$ & $3.7 \%$ & 0.8 & 3.4 & 3 & 0 \\
& & 1 & $\%)$ & $\%)$ & 7 & 6 \\
\hline
\end{tabular}

Key: $S . A=$ strongly agree $A=$ Agree $S . D=$ strongly disagree $D=$ disagree

Response to research question 3 on the significance of healthcare providers' factor on adoption of EMR by the two healthcare facilities shows that healthcare providers' factor has a moderate influence on the adoption of EMR. These findings corroborate with the prior research in the field of medical informatics. Krist et al., 2015 identified some of the barriers to EMR system adoption among many healthcare providers. Healthcare providers may be reluctant to accept EMR technology for a number of reasons, including the perception that the use of an EMR system requires extensive training, and interferes with the quality of physician-patient interaction. Moreso, other factors include, spending more time to get acquainted with the system, etcetera. While the validity of these issues have been addressed in a number of previous studies, it is important to note that healthcare providers' acceptance of EMR technology is dependent on the healthcare providers' perceptions.

Table 5: Significance of healthcare providers' factor on adoption of EMR by the two healthcare facilities.

\begin{tabular}{|c|c|c|c|c|c|c|c|}
\hline & Healthcare providers' factors & S.A & $\mathbf{A}$ & S.D & $\mathbf{D}$ & $\bar{x}$ & $\begin{array}{l}\text { S } \\
\text { D }\end{array}$ \\
\hline 1 & $\begin{array}{l}\text { Users of the EMR can make use of computers connected to the } \\
\text { internet. }\end{array}$ & $\begin{array}{l}65(2 \\
9.3 \%\end{array}$ & $\begin{array}{l}130(5 \\
8.6 \%)\end{array}$ & $\begin{array}{l}11(5 . \\
0 \%)\end{array}$ & $\begin{array}{l}10(4 . \\
5 \%)\end{array}$ & $\begin{array}{l}1 . \\
8 \\
4\end{array}$ & $\begin{array}{l}7 \\
2\end{array}$ \\
\hline 2 & $\begin{array}{l}\text { Users of the EMR in our healthcare facility have had series or } \\
\text { little experience on the use of EMR. }\end{array}$ & $\begin{array}{l}52(2 \\
3.4 \% \\
\end{array}$ & $\begin{array}{l}127(5 \\
7.2 \%)\end{array}$ & $\begin{array}{l}18(8 . \\
1 \%)\end{array}$ & $\begin{array}{l}19(8 . \\
6 \%)\end{array}$ & $\begin{array}{l}2 . \\
0 \\
2\end{array}$ & $\begin{array}{l}8 \\
2\end{array}$ \\
\hline 3 & $\begin{array}{l}\text { The users of the EMR can work perfectly and perform critical } \\
\text { operations on the EMR with little or no supervision. }\end{array}$ & $\begin{array}{l}50(2 \\
2.5 \% \\
)\end{array}$ & $\begin{array}{l}115(5 \\
1.8 \%)\end{array}$ & $\begin{array}{l}25(1 \\
1.3 \% \\
)\end{array}$ & $\begin{array}{l}28(1 \\
2.6 \% \\
)\end{array}$ & $\begin{array}{l}2 . \\
1 \\
4\end{array}$ & $\begin{array}{l}9 \\
2\end{array}$ \\
\hline 4 & $\begin{array}{l}\text { More task were achieved by the users of the EMR when } \\
\text { compared to the manual method. }\end{array}$ & $\begin{array}{l}79(3 \\
5.6 \% \\
\end{array}$ & $\begin{array}{l}101(4 \\
5.5 \%)\end{array}$ & $\begin{array}{l}15(6 . \\
8 \%)\end{array}$ & $\begin{array}{l}26(1 \\
1.7 \% \\
)\end{array}$ & $\begin{array}{l}1 . \\
9 \\
4\end{array}$ & 9 \\
\hline 5 & $\begin{array}{l}\text { Users understands basic functions of the hardware } \\
\text { components. }\end{array}$ & $\begin{array}{l}52(2 \\
3.4 \% \\
)\end{array}$ & $\begin{array}{l}136(6 \\
1.3 \%)\end{array}$ & $\begin{array}{l}17(7 . \\
7 \%)\end{array}$ & $\begin{array}{l}15(6 . \\
8 \%)\end{array}$ & $\begin{array}{l}1 . \\
9 \\
7\end{array}$ & $\begin{array}{l}7 \\
6\end{array}$ \\
\hline 6 & $\begin{array}{l}\text { Users can transfer patients files via the hospital network to } \\
\text { other healthcare professionals within our healthcare facility }\end{array}$ & $\begin{array}{l}68(3 \\
0.6 \% \\
)\end{array}$ & $\begin{array}{l}122(5 \\
5.0 \%)\end{array}$ & $\begin{array}{l}19(8 . \\
6 \%)\end{array}$ & $\begin{array}{l}10(4 . \\
5 \%)\end{array}$ & $\begin{array}{l}1 . \\
8 \\
6\end{array}$ & $\begin{array}{l}7 \\
5\end{array}$ \\
\hline
\end{tabular}

Key: $S . A=$ strongly agree $A=A g r e e ~ S . D=$ strongly disagree $D=$ disagree

Result on research question 4 on the influence of funding pattern on adoption of EMR by the two healthcare facilities reveals that the influence of funding pattern is of high extent to the adoption of EMR. This is backed up by the findings from WHO, (2015), which is of the opinion that, health financing greatly influences the development, implementation, and sustainability of a national-level 
EMR/EHR. It is also stated that even when there is substantial donor support for the information system, there are direct and indirect costs for hardware, software, routine maintenance, and any necessary security enhancements. There were also costs to network the health facilities internally and externally. Human resources costs also apply to the development and maintenance of the EMR, including training costs (which are continuous owing to staff turnover and the need for refresher trainings); change management; and logistics, such as transport and fuel costs.

Table 6: Influence of funding pattern on the adoption of EMR by the two healthcare facilities.

\begin{tabular}{|c|c|c|c|c|c|c|c|}
\hline & Funding Pattern & S.A & A & S.D & D & $\bar{x}$ & SD \\
\hline 1 & $\begin{array}{l}\text { Finance and maintenance of the EMR system is very expensive for the healthcare facility to fund or } \\
\text { monetarise. }\end{array}$ & $\begin{array}{l}83(37.4 \\
\%)\end{array}$ & $\begin{array}{l}96(43.2 \\
\%)\end{array}$ & $\begin{array}{l}26(11.7 \\
\%)\end{array}$ & $\begin{array}{l}17(7.7 \\
\%)\end{array}$ & $\begin{array}{l}1.8 \\
9\end{array}$ & .89 \\
\hline 2 & The EMR system is solely financed by our healthcare facility & $\begin{array}{l}61(27.5 \\
\%)\end{array}$ & $\begin{array}{l}104(46.8 \\
\%)\end{array}$ & $\begin{array}{l}21(9.5 \\
\%)\end{array}$ & $\begin{array}{l}27(12.2 \\
\%)\end{array}$ & $\begin{array}{l}2.0 \\
7\end{array}$ & .94 \\
\hline 3 & $\begin{array}{l}\text { The amount generated from internal revenue is enough in financing and maintaining the EMR } \\
\text { system in our healthcare facility. }\end{array}$ & $\begin{array}{l}48(21.6 \\
\%)\end{array}$ & $\begin{array}{l}81(36.5 \\
\%)\end{array}$ & $\begin{array}{l}52(23.4 \\
\%)\end{array}$ & $\begin{array}{l}37(16.7 \\
\%)\end{array}$ & $\begin{array}{l}2.3 \\
6\end{array}$ & $\begin{array}{l}1.0 \\
1\end{array}$ \\
\hline 4 & $\begin{array}{l}\text { The EMR system in use in our healthcare facility is financed through donations and other financial } \\
\text { sources. }\end{array}$ & $\begin{array}{l}33(14.9 \\
\%)\end{array}$ & $\begin{array}{l}82(36.9 \\
\%)\end{array}$ & $\begin{array}{l}55(24.8 \\
\%)\end{array}$ & $\begin{array}{l}50(22.5 \\
\%)\end{array}$ & $\begin{array}{l}2.5 \\
5\end{array}$ & $\begin{array}{l}1.0 \\
0\end{array}$ \\
\hline 5 & $\begin{array}{l}\text { Our healthcare facility secure loans through commercial banks, finance houses or cooperative } \\
\text { societies to fund the EMR system. }\end{array}$ & $\begin{array}{l}39(17.6 \\
\%)\end{array}$ & $\begin{array}{l}57(25.7 \\
\%)\end{array}$ & $\begin{array}{l}60(27.0 \\
\%)\end{array}$ & $\begin{array}{l}59(26.6 \\
\%)\end{array}$ & $\begin{array}{l}2.6 \\
4\end{array}$ & $\begin{array}{l}1.0 \\
7\end{array}$ \\
\hline
\end{tabular}

\section{Key: $S . A=$ strongly agree $A=$ Agree $S . D=$ strongly disagree $D=$ disagree}

Response on research question 5 on the quality of EMR by the two healthcare facilities shows that the quality of EMR is moderate in the two healthcare facilities. The findings of Ajoye, (2014), also supported this finding, as the author found that highly rated information system are expected to be reliable, user friendly, fast response, while also offering every functionality that places it above or at least at equal value with competing systems elsewhere. Ease of use could also be a relative term especially where one set are more technology inclined than the other. The author also opined that, the study confirms the universality of the system quality attribute in predicting information system performance. The author further analysed that performance of service personnel in response to complaint and issues arising from system irregularities is used in measuring Service quality. The responsiveness of support staff goes a long way in solving problems encountered by users. In addition to this is the technical competence of the support personnel, which is equally vital in addressing complexities associated with system attributes.

Shaw et. al. (2002) found a relationship between service quality and user satisfaction and identified software upgrades, staff response time, and documentation of training materials as the service quality factors having the most influence on user satisfaction. Sam et al. (2005) also surveyed healthcare professionals' computer skills and found that vendors have underestimated the actual skill level required to operate their systems effectively. 
Table 7: Quality of EMR in the two healthcare facilities.

\begin{tabular}{|c|c|c|c|c|c|c|c|}
\hline & EMR SYSTEM QUALITY & S.A & $\mathbf{A}$ & S.D & D & $\bar{x}$ & $\begin{array}{l}\text { S } \\
\text { D }\end{array}$ \\
\hline 1 & Is easy to use & $\begin{array}{l}71(32 . \\
0 \%)\end{array}$ & $\begin{array}{l}120(5 \\
4.1 \%)\end{array}$ & $\begin{array}{l}11(5 \\
.0 \%)\end{array}$ & $\begin{array}{l}19(8 . \\
6 \%)\end{array}$ & $\begin{array}{l}1 . \\
9 \\
0\end{array}$ & $\begin{array}{l}0 . \\
8 \\
4\end{array}$ \\
\hline 2 & Is user-friendly & $\begin{array}{l}\text { 73(32. } \\
9 \%)\end{array}$ & $\begin{array}{l}121(4 . \\
5 \%)\end{array}$ & $\begin{array}{l}10(4 \\
.5 \%)\end{array}$ & $\begin{array}{l}13(5 . \\
9 \%)\end{array}$ & $\begin{array}{l}1 . \\
8 \\
3\end{array}$ & $\begin{array}{l}0 . \\
7 \\
7\end{array}$ \\
\hline 3 & Enable me accomplish more tasks & $\begin{array}{l}66(29 . \\
7 \%)\end{array}$ & $\begin{array}{l}109(4 \\
9.1)\end{array}$ & $\begin{array}{l}22(9 \\
.9 \%)\end{array}$ & $\begin{array}{l}24(1 \\
0.8 \% \\
)\end{array}$ & $\begin{array}{l}2 . \\
0 \\
2\end{array}$ & $\begin{array}{l}0 . \\
9 \\
1\end{array}$ \\
\hline 4 & Erase duplication of actions & $\begin{array}{l}72(32 . \\
4 \%)\end{array}$ & $\begin{array}{l}121(5 \\
4.5 \%)\end{array}$ & $\begin{array}{l}10(4 \\
.5 \%)\end{array}$ & $\begin{array}{l}16(7 . \\
2 \%)\end{array}$ & $\begin{array}{l}1 . \\
8 \\
6\end{array}$ & $\begin{array}{l}0 . \\
8 \\
1\end{array}$ \\
\hline 5 & Erase medical records retrieval & $\begin{array}{l}86(38 . \\
7 \%)\end{array}$ & $\begin{array}{l}117(5 \\
2.7 \%)\end{array}$ & $\begin{array}{l}9(4 . \\
1 \%)\end{array}$ & $\begin{array}{l}7(3.2 \\
\%)\end{array}$ & $\begin{array}{l}1 . \\
7 \\
1\end{array}$ & $\begin{array}{l}0 . \\
6 \\
9\end{array}$ \\
\hline & EMR CONTENT QUALITY & S.A & A & S.D & $\mathbf{D}$ & $\bar{x}$ & $\begin{array}{l}\text { S } \\
\text { D }\end{array}$ \\
\hline 1 & $\begin{array}{l}\text { The content of the EMR in my hospital is presented in a useful } \\
\text { format }\end{array}$ & $\begin{array}{l}53(23 . \\
9 \%)\end{array}$ & $\begin{array}{l}150(6 \\
7.6 \%)\end{array}$ & $\begin{array}{l}11(5 \\
.0 \%)\end{array}$ & $\begin{array}{l}2(0.9 \\
\%)\end{array}$ & $\begin{array}{l}1 . \\
8 \\
2\end{array}$ & $\begin{array}{l}0 . \\
5 \\
5\end{array}$ \\
\hline 2 & The EMR provides an up-to-date information & $\begin{array}{l}69(31 . \\
1 \%)\end{array}$ & $\begin{array}{l}133(5 \\
9.9 \%)\end{array}$ & $\begin{array}{l}15(6 \\
.8 \%)\end{array}$ & $\begin{array}{l}4(1.8 \\
\%)\end{array}$ & $\begin{array}{l}1 . \\
7 \\
9\end{array}$ & $\begin{array}{l}0 . \\
6 \\
4\end{array}$ \\
\hline 3 & $\begin{array}{l}\text { The EMR provides information that I would need to carry on } \\
\text { my daily routine }\end{array}$ & $\begin{array}{l}63(28 . \\
4 \%)\end{array}$ & $\begin{array}{l}134(6 \\
0.4 \%)\end{array}$ & $\begin{array}{l}13(5 \\
.9 \%)\end{array}$ & $\begin{array}{l}11(5 . \\
0 \%)\end{array}$ & $\begin{array}{l}1 . \\
8 \\
7\end{array}$ & $\begin{array}{l}0 . \\
7 \\
3\end{array}$ \\
\hline 4 & $\begin{array}{l}\text { The texts, pictures and videos in the EMR system are clear } \\
\text { and legible. }\end{array}$ & $\begin{array}{l}58(26 . \\
1 \%)\end{array}$ & $\begin{array}{l}152(6 \\
8.5 \%)\end{array}$ & $\begin{array}{l}3(1 . \\
4 \%)\end{array}$ & $\begin{array}{l}6(2.7 \\
\%)\end{array}$ & $\begin{array}{l}1 . \\
8 \\
0\end{array}$ & $\begin{array}{l}0 . \\
5 \\
9\end{array}$ \\
\hline 5 & $\begin{array}{l}\text { The hyperlinks in the EMR system leads to the right } \\
\text { information }\end{array}$ & $\begin{array}{l}56(25 . \\
2 \%)\end{array}$ & $\begin{array}{l}130(5 \\
8.6 \%)\end{array}$ & $\begin{array}{l}16(7 \\
.2 \%)\end{array}$ & $\begin{array}{l}9(4.1 \\
\%)\end{array}$ & $\begin{array}{l}1 . \\
8 \\
9\end{array}$ & $\begin{array}{l}0 . \\
7 \\
1\end{array}$ \\
\hline & SUPPORT SERVICE SYSTEM & S.A & $\mathbf{A}$ & S.D & D & $\bar{x}$ & $\begin{array}{l}\text { S } \\
\text { D }\end{array}$ \\
\hline 1 & $\begin{array}{l}\text { The IT department support staff are always available for } \\
\text { consultation }\end{array}$ & $\begin{array}{l}62(27 . \\
9 \%)\end{array}$ & $\begin{array}{l}98(44 . \\
1 \%)\end{array}$ & $\begin{array}{l}15(6 \\
.8 \%)\end{array}$ & $\begin{array}{l}40(1 \\
8.0 \% \\
)\end{array}$ & $\begin{array}{l}2 . \\
1 \\
5\end{array}$ & $\begin{array}{l}1 . \\
0 \\
4\end{array}$ \\
\hline 2 & The IT department support staff provides satisfactory help & $\begin{array}{l}50(22 . \\
5 \%)\end{array}$ & $\begin{array}{l}117(5 \\
2.7 \%)\end{array}$ & $\begin{array}{l}14(6 \\
.3 \%)\end{array}$ & $\begin{array}{l}34(1 \\
5.3 \% \\
)\end{array}$ & $\begin{array}{l}2 . \\
1 \\
5\end{array}$ & $\begin{array}{l}.9 \\
6\end{array}$ \\
\hline
\end{tabular}




\begin{tabular}{|c|c|c|c|c|c|c|c|}
\hline 3 & Technical support team provides after sales service & $\begin{array}{l}47(21 . \\
2 \%)\end{array}$ & $\begin{array}{l}92(41 . \\
4 \%)\end{array}$ & $\begin{array}{l}17(7 \\
.7 \%)\end{array}$ & $\begin{array}{l}43(1 \\
9.4 \% \\
)\end{array}$ & $\begin{array}{l}2 . \\
2 \\
8\end{array}$ & $\begin{array}{l}1 . \\
0 \\
5\end{array}$ \\
\hline 4 & Technical support team's after-sales services are reliable & $\begin{array}{l}36(16 . \\
2 \%)\end{array}$ & $\begin{array}{l}113(5 \\
0.9 \%)\end{array}$ & $\begin{array}{l}15(6 \\
.8 \%)\end{array}$ & $\begin{array}{l}34(1 \\
5.3 \% \\
)\end{array}$ & $\begin{array}{l}2 . \\
2 \\
4\end{array}$ & $\begin{array}{l}.9 \\
4\end{array}$ \\
\hline 5 & $\begin{array}{l}\text { The after-sales services provided by the technical support } \\
\text { team is sufficient }\end{array}$ & $\begin{array}{l}42(18 . \\
9 \%)\end{array}$ & $\begin{array}{l}95(42 . \\
8 \%)\end{array}$ & $\begin{array}{l}12(5 \\
.4 \%)\end{array}$ & $\begin{array}{l}53(2 \\
3.9 \% \\
)\end{array}$ & $\begin{array}{l}2 . \\
3 \\
8\end{array}$ & $\begin{array}{l}1 . \\
0 \\
9\end{array}$ \\
\hline 6 & Technical support team are considerate & $\begin{array}{l}33(14 . \\
9 \%)\end{array}$ & $\begin{array}{l}140(6 \\
3.1 \%)\end{array}$ & $\begin{array}{l}12(5 \\
.4 \%)\end{array}$ & $\begin{array}{l}26(1 \\
1.7 \% \\
)\end{array}$ & $\begin{array}{l}2 . \\
1 \\
4\end{array}$ & $\begin{array}{l}.8 \\
3\end{array}$ \\
\hline 7 & Technical support team are competent & $\begin{array}{l}37(16 . \\
7 \%)\end{array}$ & $\begin{array}{l}143(6 \\
4.4 \%)\end{array}$ & $\begin{array}{l}9(4 . \\
1 \%)\end{array}$ & $\begin{array}{l}22(9 . \\
9 \%)\end{array}$ & $\begin{array}{l}2 . \\
0 \\
8\end{array}$ & $\begin{array}{l}.8 \\
0\end{array}$ \\
\hline & $\begin{array}{l}\text { HCP SELF-R } \\
\text { LEARNING }\end{array}$ & S.A & A & S.D & D & $\bar{x}$ & $\begin{array}{l}\text { S } \\
\mathbf{D}\end{array}$ \\
\hline 1 & I am aware of EMR before its adoption in this hospital & $\begin{array}{l}77(34 . \\
7 \%)\end{array}$ & $\begin{array}{l}84(37 . \\
8 \%)\end{array}$ & $\begin{array}{l}5(2 . \\
3 \%)\end{array}$ & $\begin{array}{l}53(2 \\
3.9 \% \\
)\end{array}$ & $\begin{array}{l}2 . \\
1 \\
6\end{array}$ & $\begin{array}{l}1 . \\
1 \\
5\end{array}$ \\
\hline 2 & $\begin{array}{l}\text { I have explored on the internet on how it is being used before } \\
\text { its adoption in this hospital }\end{array}$ & $\begin{array}{l}57(25 . \\
7 \%)\end{array}$ & $\begin{array}{l}75(33 . \\
8 \%)\end{array}$ & $\begin{array}{l}16(7 \\
.2 \%)\end{array}$ & $\begin{array}{l}73(3 \\
2.9 \% \\
) \\
\end{array}$ & $\begin{array}{l}2 . \\
4 \\
8 \\
\end{array}$ & $\begin{array}{l}1 . \\
1 \\
9\end{array}$ \\
\hline 3 & $\begin{array}{l}\text { Using the system, I have learned how to trouble shoot } \\
\text { problems without involving an IT support staff }\end{array}$ & $\begin{array}{l}40(18 . \\
0 \%)\end{array}$ & $\begin{array}{l}88(39 . \\
6 \%)\end{array}$ & $\begin{array}{l}21(9 \\
.5 \%)\end{array}$ & $\begin{array}{l}69(3 \\
1.1 \% \\
)\end{array}$ & $\begin{array}{l}2 . \\
5 \\
5 \\
\end{array}$ & $\begin{array}{l}1 . \\
1 \\
2 \\
\end{array}$ \\
\hline 4 & $\begin{array}{l}\text { I can perfectly use more than one module on the EMR } \\
\text { software in this hospital }\end{array}$ & $\begin{array}{l}48(21 . \\
6 \%)\end{array}$ & $\begin{array}{l}118(5 \\
3.2 \%)\end{array}$ & $\begin{array}{l}12(5 \\
.4 \%)\end{array}$ & $\begin{array}{l}41(1 \\
8.5 \% \\
)\end{array}$ & $\begin{array}{l}2 . \\
2 \\
1 \\
\end{array}$ & $\begin{array}{l}.9 \\
9\end{array}$ \\
\hline 5 & $\begin{array}{l}\text { Using self-regulated learning has helped me to solve many } \\
\text { problems in the use of the EMR software in this hospital }\end{array}$ & $\begin{array}{l}51(23 . \\
0 \%)\end{array}$ & $\begin{array}{l}102(4 \\
5.9 \%)\end{array}$ & $\begin{array}{l}12(5 \\
.4 \%)\end{array}$ & $\begin{array}{l}48(2 \\
1.6 \% \\
)\end{array}$ & $\begin{array}{l}2 . \\
2 \\
7\end{array}$ & $\begin{array}{l}1 . \\
0 \\
6\end{array}$ \\
\hline & HOSPITAL PREPAREDNESS & S.A & A & S.D & $\mathbf{D}$ & $\bar{x}$ & $\begin{array}{l}\text { S } \\
\mathbf{D}\end{array}$ \\
\hline 1 & The IT equipment were put in place & $\begin{array}{l}61(27 . \\
5 \%)\end{array}$ & $\begin{array}{l}124(5 \\
5.9 \%)\end{array}$ & $\begin{array}{l}12(5 \\
.4 \%)\end{array}$ & $\begin{array}{l}25(1 \\
1.3 \% \\
)\end{array}$ & $\begin{array}{l}2 . \\
0 \\
0\end{array}$ & $\begin{array}{l}.8 \\
8\end{array}$ \\
\hline 2 & The building space was big enough to house the equipment & $\begin{array}{l}58(26 . \\
1 \%)\end{array}$ & $\begin{array}{l}120(5 \\
4.1 \%)\end{array}$ & $\begin{array}{l}20(9 \\
.0 \%)\end{array}$ & $\begin{array}{l}24(1 \\
0.8 \% \\
)\end{array}$ & $\begin{array}{l}2 . \\
0 \\
5\end{array}$ & $\begin{array}{l}.8 \\
9\end{array}$ \\
\hline 3 & $\begin{array}{l}\text { Substitute of the EMR software was made available in case } \\
\text { the present EMR crashes. }\end{array}$ & $\begin{array}{l}42(18 . \\
9 \%)\end{array}$ & $\begin{array}{l}131(5 \\
9.0 \%)\end{array}$ & $\begin{array}{l}11(5 \\
.0 \%)\end{array}$ & $\begin{array}{l}24(1 \\
0.8 \% \\
)\end{array}$ & $\begin{array}{l}2 . \\
0 \\
8 \\
\end{array}$ & $\begin{array}{l}.8 \\
4\end{array}$ \\
\hline 4 & Funding of the IT project was adequate & $\begin{array}{l}43(19 . \\
4 \%)\end{array}$ & $\begin{array}{l}113(5 \\
0.9 \%)\end{array}$ & $\begin{array}{l}20(9 \\
.0 \%)\end{array}$ & $\begin{array}{l}37(1 \\
6.7 \% \\
)\end{array}$ & $\begin{array}{l}2 . \\
2 \\
4\end{array}$ & $\begin{array}{l}.9 \\
7\end{array}$ \\
\hline
\end{tabular}




\begin{tabular}{|c|c|c|c|c|c|c|c|}
\hline 5 & Staff were trained on how to operate the EMR system & $\begin{array}{l}\text { 62(27. } \\
9 \%)\end{array}$ & $\begin{array}{l}143(6 \\
4.4 \%)\end{array}$ & $\begin{array}{l}6(2 . \\
7 \%)\end{array}$ & $\begin{array}{l}10(4 . \\
5 \%)\end{array}$ & $\begin{array}{l}1 . \\
8 \\
4\end{array}$ & $\begin{array}{l}.6 \\
8\end{array}$ \\
\hline & HCP SATISFACTION & S.A & $\mathbf{A}$ & S.D & D & $\bar{x}$ & $\begin{array}{l}\text { S } \\
\text { D }\end{array}$ \\
\hline 1 & The system meets our needs & $\begin{array}{l}72(32 . \\
4 \%)\end{array}$ & $\begin{array}{l}124(5 \\
5.9 \%)\end{array}$ & $\begin{array}{l}7(3 . \\
2 \%)\end{array}$ & $\begin{array}{l}18(8 . \\
1 \%)\end{array}$ & $\begin{array}{l}1 . \\
8 \\
7\end{array}$ & $\begin{array}{l}.8 \\
2\end{array}$ \\
\hline 2 & The system is efficient & $\begin{array}{l}72(32 . \\
44 \%)\end{array}$ & $\begin{array}{l}128(5 \\
7.7 \%)\end{array}$ & $\begin{array}{l}6(2 . \\
7 \%)\end{array}$ & $\begin{array}{l}16(7 . \\
2 \%)\end{array}$ & $\begin{array}{l}1 . \\
8 \\
5\end{array}$ & $\begin{array}{l}.7 \\
9\end{array}$ \\
\hline 3 & The system is sustainable & $\begin{array}{l}73(32 . \\
9 \%)\end{array}$ & $\begin{array}{l}118(5 \\
3.2 \%)\end{array}$ & $\begin{array}{l}9(4 . \\
1 \%)\end{array}$ & $\begin{array}{l}20(9 . \\
0 \%)\end{array}$ & $\begin{array}{l}1 . \\
8 \\
9\end{array}$ & $\begin{array}{l}.8 \\
5\end{array}$ \\
\hline 4 & The system meets our expectation & $\begin{array}{l}67(30 . \\
2 \%)\end{array}$ & $\begin{array}{l}114(5 \\
1.4 \%)\end{array}$ & $\begin{array}{l}20(9 \\
.0 \%)\end{array}$ & $\begin{array}{l}18(8 . \\
1 \%)\end{array}$ & $\begin{array}{l}1 . \\
9 \\
5\end{array}$ & $\begin{array}{l}.8 \\
5\end{array}$ \\
\hline 5 & The system relieves us from stress & $\begin{array}{l}83(37 . \\
4 \%)\end{array}$ & $\begin{array}{l}108(4 \\
8.6 \%)\end{array}$ & $\begin{array}{l}9(4 . \\
1 \%)\end{array}$ & $\begin{array}{l}22(9 . \\
9 \%)\end{array}$ & $\begin{array}{l}1 . \\
8 \\
6\end{array}$ & $\begin{array}{l}.8 \\
9\end{array}$ \\
\hline 6 & The system help us attend to more than enough patients daily. & $\begin{array}{l}67(30 . \\
2 \%)\end{array}$ & $\begin{array}{l}99(44 . \\
6 \%)\end{array}$ & $\begin{array}{l}19(8 \\
.6 \%)\end{array}$ & $\begin{array}{l}34(1 \\
5.3 \% \\
)\end{array}$ & $\begin{array}{l}2 . \\
0 \\
9\end{array}$ & $\begin{array}{l}1 . \\
0 \\
0\end{array}$ \\
\hline 7 & Overall, we are satisfied with the system & $\begin{array}{l}68(30 . \\
6 \%)\end{array}$ & $\begin{array}{l}123(5 \\
5.4 \%)\end{array}$ & $\begin{array}{l}8(3 . \\
6 \%)\end{array}$ & $\begin{array}{l}18(8 . \\
1 \%)\end{array}$ & $\begin{array}{l}1 . \\
8 \\
9\end{array}$ & $\begin{array}{l}.8 \\
2\end{array}$ \\
\hline
\end{tabular}

Key: $S . A=$ strongly agree $A=$ Agree $S$. $D=$ strongly disagree $D=$ disagree

Response on research question 6 on the system success of EMR by the two healthcare facilities shows that EMR system success is on the high side in the two healthcare facilities. The findings validate Ndukwe and Ezeoha (2018) who found out that there are many benefits of EMR to both the healthcare providers and consumer (patients) like fast access, storage, privacy, support, accessibility, affordability, technology, basic facilities, flexibility, efficiency, and manageability, etcetera. Much earlier findings from Fraser, Biodich,Moodley, Choi, Mamlin, and Szolovits (2005) also find out that EMRs and other decision support tools like computerised physician order entry (CPOE) help to reduce medical errors. For example, some clinical information systems (CIS) are able to check for drug allergies, drug doses and appropriateness of medication, thereby eliminating the need for physicians to write orders by hand in the patient's chart. Another important element of an EMR is legibility of clinical notes. An EMR provides documentation in a computerised format that allows for data or records to be printed in text form rather than hand written. Also the computer makes spelling, validity and range checks which prompt users when data entry error is detected. An EMR also increases efficiency of healthcare providers' workflow. Thus, data entered into the hospital information system (HIS) can be used to refer a patient to a specialist.

Also, the findings corroborate with Fraser, Biodich, Moodley, Choi, Mamlin and Szolovits (2005). The author states that EMR allows care providers an opportunity to be abreast of patient health status. For instance, by creating shortcuts to documents warning about abnormal laboratory examination results, prescriptions and drug administration, physicians are able to quickly provide 
feedback to patients without any difficulties. Other identified benefits of EMR include data accessibility by multiple users and continuous data processing as well as automatic data back up and stored at different locations outside the hospital or clinics so that in case of disaster access to the record will not be denied. It can be concluded that the benefits offered by the EMR system, in terms of efficiency and profitability is important in measuring the success of the system.

Table 8: System success of the adopted EMR in the two healthcare facilities

\begin{tabular}{|c|c|c|c|c|c|c|c|}
\hline $\begin{array}{l}\mathbf{S} \\
/ \\
\mathbf{N}\end{array}$ & Question Items: & SA & A & SD & D & $\bar{x}$ & \\
\hline 1 & $\begin{array}{l}\text { Application of EMR into our routine has increased the hospitals' } \\
\text { efficiency. }\end{array}$ & $\begin{array}{l}62( \\
27 . \\
9 \%\end{array}$ & $\begin{array}{l}138 \\
(62 . \\
2 \%\end{array}$ & $\begin{array}{l}9(4 \\
.1 \\
\%)\end{array}$ & $\begin{array}{l}13( \\
5.9 \\
\%\end{array}$ & $\begin{array}{l}1 \\
8 \\
8 \\
8\end{array}$ & $\begin{array}{l}7 \\
4\end{array}$ \\
\hline 2 & $\begin{array}{l}\text { The EMR system speed up the internal communication between } \\
\text { healthcare personnel. }\end{array}$ & $\begin{array}{l}65( \\
29 . \\
3 \%\end{array}$ & $\begin{array}{l}135 \\
(60 . \\
8 \%\end{array}$ & $\begin{array}{l}7(3 \\
.2 \\
\%)\end{array}$ & $\begin{array}{l}13( \\
5.9 \\
\%\end{array}$ & $\begin{array}{l}1 \\
8 \\
8 \\
5\end{array}$ & $\begin{array}{l}7 \\
4\end{array}$ \\
\hline 3 & $\begin{array}{l}\text { Documentation, consultation and prescription, dispensing of drugs and } \\
\text { appointment system with the use of EMR has increased our } \\
\text { performance compared to the traditional method. }\end{array}$ & $\begin{array}{l}56( \\
25 . \\
2 \%\end{array}$ & $\begin{array}{l}137 \\
(61 . \\
7 \%\end{array}$ & $\begin{array}{l}11( \\
5.0 \\
\%\end{array}$ & $\begin{array}{l}17( \\
7.7 \\
\%\end{array}$ & $\begin{array}{l}1 \\
9 \\
5\end{array}$ & $\begin{array}{l}7 \\
8\end{array}$ \\
\hline 4 & $\begin{array}{l}\text { Waiting time of patients has been drastically reduced with the use of } \\
\text { EMR. }\end{array}$ & $\begin{array}{l}63( \\
28 . \\
4 \% \\
)\end{array}$ & $\begin{array}{l}138 \\
(62 . \\
2 \%)\end{array}$ & $\begin{array}{l}5(2 \\
3 \\
\%)\end{array}$ & $\begin{array}{l}15( \\
6.8 \\
\%)\end{array}$ & $\begin{array}{l}1 \\
8 \\
8 \\
7\end{array}$ & $\begin{array}{l}7 \\
5\end{array}$ \\
\hline 5 & $\begin{array}{l}\text { EMR has helped us revisit the long-abandoned waiting list procedure } \\
\text { in the admission of patients. }\end{array}$ & $\begin{array}{l}28( \\
12 . \\
6 \% \\
)\end{array}$ & $\begin{array}{l}114 \\
(51 . \\
4 \%)\end{array}$ & $\begin{array}{l}26( \\
11 . \\
7 \% \\
)\end{array}$ & $\begin{array}{l}49( \\
22 . \\
1 \% \\
)\end{array}$ & $\begin{array}{l}2 \\
4 \\
4 \\
\end{array}$ & $\begin{array}{l}9 \\
8\end{array}$ \\
\hline 6 & $\begin{array}{l}\text { Research activities pertaining to patients health, epidemic and } \\
\text { pandemic diseases have been made easy by the use of EMR }\end{array}$ & $\begin{array}{l}34( \\
15 . \\
3 \% \\
)\end{array}$ & $\begin{array}{l}173 \\
(77 . \\
9 \%)\end{array}$ & $\begin{array}{l}4(1 \\
.8 \\
\%)\end{array}$ & $\begin{array}{l}9(4 \\
.1 \\
\%)\end{array}$ & $\begin{array}{l}1 \\
9 \\
9 \\
5\end{array}$ & $\begin{array}{l}5 \\
8\end{array}$ \\
\hline 7 & $\begin{array}{l}\text { Stress encountered through the search and retrieving of missed } \\
\text { casenotes has declined through the use of EMR, }\end{array}$ & $\begin{array}{l}55( \\
24 . \\
8 \% \\
)\end{array}$ & $\begin{array}{l}149 \\
(67 . \\
1 \%)\end{array}$ & $\begin{array}{l}14( \\
6.3 \\
\%)\end{array}$ & $\begin{array}{l}3(1 \\
.4 \\
\%)\end{array}$ & $\begin{array}{l}1 \\
8 \\
4 \\
4\end{array}$ & $\begin{array}{l}5 \\
5 \\
9\end{array}$ \\
\hline 8 & $\begin{array}{l}\text { e-documentation, e-consultation and e-prescription, e-administration } \\
\text { of drugs and e-appointment system within the healthcare facility has } \\
\text { increased our revenue. }\end{array}$ & $\begin{array}{l}40( \\
18 . \\
0 \% \\
\end{array}$ & $\begin{array}{l}150 \\
(67 . \\
6 \%)\end{array}$ & $\begin{array}{l}11( \\
5.0 \\
\%)\end{array}$ & $\begin{array}{l}13( \\
5.9 \\
\%)\end{array}$ & $\begin{array}{l}1 \\
9 \\
9\end{array}$ & $\begin{array}{l}7 \\
7 \\
0\end{array}$ \\
\hline 9 & $\begin{array}{l}\text { The use of EMR has brought about increment in the number of } \\
\text { patients who attends our hospital and this had in turn increased the } \\
\text { turnover per year. }\end{array}$ & $\begin{array}{l}38( \\
17 . \\
1 \%\end{array}$ & $\begin{array}{l}154 \\
(69 . \\
4 \%\end{array}$ & $\begin{array}{l}4(1 \\
8 \\
\%)\end{array}$ & $\begin{array}{l}16( \\
7.2 \\
\%\end{array}$ & $\begin{array}{l}1 \\
9 \\
9\end{array}$ & $\begin{array}{l}7 \\
1\end{array}$ \\
\hline $\begin{array}{l}1 \\
0\end{array}$ & Easy statistical compilation through the use of EMR & $\begin{array}{l}48( \\
21 .\end{array}$ & $\begin{array}{l}145 \\
(65 .\end{array}$ & $\begin{array}{l}8(3 \\
.6\end{array}$ & $\begin{array}{l}8(3 \\
.6\end{array}$ & 1 & 6 \\
\hline
\end{tabular}




\begin{tabular}{|c|c|c|c|c|c|c|c|}
\hline & & $\begin{array}{l}6 \% \\
6 \%\end{array}$ & $3 \%)$ & \%) & $\%)$ & $\begin{array}{l}8 \\
9\end{array}$ & 4 \\
\hline $\begin{array}{l}1 \\
1\end{array}$ & Hospital revenue has increased over time through the use of EMR. & $\begin{array}{l}41( \\
18 . \\
5 \%\end{array}$ & $\begin{array}{l}137 \\
(61 . \\
7 \%\end{array}$ & $\begin{array}{l}11( \\
5.0 \\
\%\end{array}$ & $\begin{array}{l}20( \\
9.0 \\
\%\end{array}$ & $\begin{array}{l}2 \\
0 \\
5\end{array}$ & $\begin{array}{l}8 \\
0\end{array}$ \\
\hline $\begin{array}{l}1 \\
2\end{array}$ & $\begin{array}{l}\text { Running cost that were cut from the use of EMR as against payment } \\
\text { of staff in operating paper records has help us with our financial } \\
\text { liquidity. }\end{array}$ & $\begin{array}{l}50( \\
22 . \\
5 \%\end{array}$ & $\begin{array}{l}133 \\
(59 . \\
9 \%\end{array}$ & $\begin{array}{l}9(4 \\
.1 \\
\%)\end{array}$ & $\begin{array}{l}20( \\
9.0 \\
\%\end{array}$ & $\begin{array}{l}2 \\
0 \\
0\end{array}$ & $\begin{array}{l}8 \\
8 \\
1\end{array}$ \\
\hline $\begin{array}{l}1 \\
3\end{array}$ & $\begin{array}{l}\text { The net profit generated from using EMR for patients' satisfaction can } \\
\text { take care of our long-term financial needs. }\end{array}$ & $\begin{array}{l}42( \\
18 . \\
9 \%\end{array}$ & $\begin{array}{l}143 \\
(64 . \\
4 \%\end{array}$ & $\begin{array}{l}11( \\
5.0 \\
\%\end{array}$ & $\begin{array}{l}18( \\
8.1 \\
\%\end{array}$ & $\begin{array}{l}2 \\
0 \\
2\end{array}$ & $\begin{array}{l}7 \\
7\end{array}$ \\
\hline $\begin{array}{l}1 \\
4\end{array}$ & The overall hospital performance has improved using the system & $\begin{array}{l}51( \\
23 . \\
0 \%\end{array}$ & $\begin{array}{l}110 \\
(49 . \\
5 \%\end{array}$ & $\begin{array}{l}6(2 \\
.7 \\
\%)\end{array}$ & $\begin{array}{l}9(4 \\
.1 \\
\%)\end{array}$ & $\begin{array}{l}1 \\
8 \\
8 \\
5\end{array}$ & $\begin{array}{l}. \\
7 \\
1\end{array}$ \\
\hline
\end{tabular}

Key: S. A= strongly agree $A=$ Agree $S$. $D=$ strongly disagree $D=$ disagree

\section{Summary of findings}

The study examined adoption factors, usage evaluation and EMR system success of Federal Medical Centre, Owo and Federal Teaching Hospital, Ido-Ekiti. From the data analysed and the hypotheses tested, the findings revealed that:

i. Technological factors have a moderate influence on adoption of EMR in Federal Medical Centre,

Owo and Federal Teaching Hospital, Ido.

ii. Organisational factor has a high significance on the adoption of EMR in Federal medical center,

Owo and Federal teaching hospital, Ido.

iii. Healthcare providers' factor has a moderate significance on the adoption of EMR.

iv. The influence of funding pattern is of high extent to the adoption of EMR.

v. EMR adopted in Federal Medical Centre, Owo and Federal Teaching hospital, Ido is of moderate quality.

vi. EMR system usage has moderately succeeded in the two healthcare facilities.

\section{Conclusion and recommendations}

The study concludes that usage evaluation of EMR influenced EMR system success of Federal Medical Centre Owo and Federal Teaching Hospital, Ido-Ekiti. It was concluded that all the constructs for EMR usage evaluation (EMR system quality, EMR content quality, EMR support service system, healthcare professionals self-regulated learning, hospital preparedness and healthcare professional satisfaction) led to EMR system success. Therefore, usage evaluation factors were concluded to be significant predictors of electronic medical records (EMR) system success in Federal Medical Centre Owo and Federal Teaching Hospital, Ido-Ekiti. In view of the findings, the study therefore recommends that:

1. Standard, intense and continuous training activities should be provided for all medical/health personnel. This is in order to keep them abreast of the benefits EMR can offer to their routines. This would help them develop interest in the use of EMR. 
2. Technological factors such as information quality, system quality, content quality and output quality should be considered by healthcare facilities before the adoption of EMR.

3. More emphasis should be placed on the organisational factors (top management support, subordinate feedback and training), most especially the top management support, for the success of the adopted EMR.

4. Users of the EMR should also be trained on how to troubleshoot problems encountered with the use of EMR, in case the IT personnel or service support staff are not available.

5. Healthcare providers should be willing to explore on the use of EMR through various internet sources, so as to increase their expertise.

6. Healthcare facilities should conduct pre-implementation and post-implementation evaluation of the EMR so as to determine the proper adoption and usage of the EMR.

7. The management of the healthcare facilities should diversify the source of fund for the EMR system in their various hospitals, as majority of the staff claimed funding of EMR was not sourced from other unconventional sources such as bank and cooperative loans.

\section{References}

Adegbore, A. M. (2018). Adoption Factors of Integrated Library Management Systems (ILMS) in Selected Nigerian University Libraries. Library Philosophy and Practice (E-Journal).

Ajoye Miss, M. B. (2014). Information systems user satisfaction: a survey of the postgraduate school portal, university of Ibadan, Nigeria. Retrieved from https://digitalcommons.unl.edu/libphilprac/1192/?utm_ on 8/3/2021

Alam, M. G. R., Masum, A. K. M., Beh, L. S., \& Hong, C. S. (2016). Critical factors influencing decision to adopt human resource information system (HRIS) in hospitals. PloS one, 11(8), e0160366

Al-Mamary, Y. H., Shamsuddin, A., \& Hamid, N. A. A. (2015). Enhancing technological capability of telecommunications sector in Yemen: a technology adoption approach. Mediterranean Journal of Social Sciences, 6(4), 108-108.

Al-Qirim, N. (2008). Personas of e-commerce adoption in small businesses in New Zealand. In Web Technologies for Commerce and Services Online (pp. 286-310). IGI Global

Bradley, R. V., Byrd, T. A., Pridmore, J. L., Thrasher, E., Pratt, R. M., \& Mbarika, V. W. (2012). An empirical examination of antecedents and consequences of IT governance in US hospitals. Journal of Information Technology, 27(2), 156-177.

Dong, S., Xu, S. X., \& Zhu, K. X. (2009). Research note-information technology in supply chains: The value of it-enabled resources under competition. Information systems research, 20(1), 18-32.

Fraser, H., Biondich, P., Moodley, D., Choi, S., Mamlin, B., \& Szolovits, P. (2005). Implementing electronic medical record systems in developing countries. Journal of Innovation in Health Informatics, 13(2), 83-95.

Gelderman, M. (2002). Task difficulty, task variability and satisfaction with management support systems. Information \& Management, 39(7), 593-604.

Hussein, R., Karim, N. S. A., \& Selamat, M. H. (2007). The impact of technological factors on information systems success in the electronic- government context. Business Process Management Journal.

Krist, A. H. (2015). Electronic health record innovations for healthier patients and happier doctors. 
Lian, J. W., Yen, D. C., \& Wang, Y. T. (2014). An exploratory study to understand the critical factors affecting the decision to adopt cloud computing in Taiwan hospital. International Journal of Information Management, 34(1), 28-36.

Macharia, F. M. (2013). Factors influencing adoption of information systems in private healthcare facilities in Kiambu county, Kenya (Doctoral dissertation, University of Nairobi).

MediFIX. 2017. Why Nigerian Hospitals Need to Start Using Electronic Medical Records. Retrieved from http://medifix.ng/2017/03/09/why-nigerian-hospitals-need-to-startusing-electronicmedical-records/

Ndukwe, C. M., \& Ezeoha, B. U. (2018). A Hybrid of Electronic Health Record (EHR) System and Health Maintenance Organizations (HMOs): A Sure Way to Improve Healthcare System in Nigeria. International Journal of Computer Science and Mathematical Theory, 4(3), 14-22.

Palmer, J. W. (2002). Web site usability, design, and performance metrics. Information systems research, 13(2), 151-167.

Shaw, C. and J. Ivens (2002), Building Great Customer Experiences. New York: Macmillan.

Uzochukwu, B., Ughasoro, M. M., Etiba, E., Okwuosa, C., Envuladu E., \& Onwujekwe, O. E. (2016). Health care financing in nigeria: implications for achieving universal health coverage. Nigerian Journal of Clinical Practice, 2015 (18), 437-4 